Article

\title{
Biodiversity of Kelp Forests and Coralline Algae Habitats in Southwestern Greenland
}

\author{
Kathryn M. Schoenrock ${ }^{1,2, * \mathbb{D}}$, Johanne Vad ${ }^{3,4}$, Arley Muth ${ }^{5}$, Danni M. Pearce ${ }^{6}$, Brice R. Rea ${ }^{7}$,
} J. Edward Schofield ${ }^{7}$ and Nicholas A. Kamenos ${ }^{1}$

1 School of Geographical and Earth Sciences, University of Glasgow, Gregory Building, Lilybank Gardens, Glasgow G12 8QQ, UK; nick.kamenos@glasgow.ac.uk

2 Botany and Plant Science, National University of Ireland Galway, Ryan Institute, University Rd., H91 TK33 Galway, Ireland

3 School of Engineering, Geosciences, Infrastructure and Society, Heriot-Watt University, Riccarton Campus, Edinburgh EH14 4AS, UK; jv63@hw.ac.uk

4 School of Geosciences, Grant Institute, University of Edinburgh, Edinburgh EH28 8, UK

5 Marine Science Institute, The University of Texas at Austin, College of Natural Sciences, 750 Channel View Drive, Port Aransas, TX 78373-5015, USA; arley.muth@utexas.edu

6 Department of Biological and Environmental Sciences, School of Life and Medical Sciences, University of Hertfordshire, Hatfield, Hertfordshire AL10 9AB, UK; d.pearce20@herts.ac.uk

7 Geography \& Environment, School of Geosciences, University of Aberdeen, Elphinstone Road, Aberdeen AB24 3UF, UK; b.rea@abdn.ac.uk (B.R.R.); j.e.schofield@abdn.ac.uk (J.E.S.)

* Correspondence: kathryn.schoenrock@nuigalway.ie; Tel.: +353-87-637-2869

Received: 22 August 2018; Accepted: 22 October 2018; Published: 25 October 2018

\begin{abstract}
All marine communities in Greenland are experiencing rapid environmental change, and to understand the effects on those structured by seaweeds, baseline records are vital. The kelp and coralline algae habitats along Greenland's coastlines are rarely studied, and we fill this knowledge gap for the area around Nuuk, west Greenland. Using subtidal swath surveys, photo-quadrats, and grab samples, we characterised the diversity of floral and faunal assemblages in kelp forests and coralline algae beds. The most abundant herbivore assemblages and the most diverse communities occur in the interstitial habitats of rhodolith beds. In kelp forests, species diversity is higher in epi-benthic (photo-quadrat) and mid-water (swath) surveys. These habitats are not mutually exclusive; Agarum clathratum is prominent in coralline algal habitats, while crustose coralline algae cover the bedrock under kelp holdfasts. Overall, the suite of surveys used capture the diverse communities within kelp forests and coralline algae in Greenland and their differing role in the life history of the inhabitants. Furthermore, coralline algae beds are an important carbonate store, with $\mathrm{CaCO}_{3}$ concentrations ranging from 28.06 to $103.73 \mathrm{~g} \cdot \mathrm{m}^{-3}$. Our research sets the baseline for continued investigations and monitoring of these important habitats and their supported fisheries.
\end{abstract}

Keywords: arctic; carbon sink; rhodolith beds; marine assemblages; climate change; Saccharina longicruris; ecosystem engineer; ecology; fisheries; food-web

\section{Introduction}

Polar marine communities are seasonal systems that rely on annual bursts of primary productivity in both pelagic and benthic communities [1]. Primary producers in these communities have many adaptations to the environmental restrictions of high latitudes (e.g., polar night, low temperature) [2] and secondary production is closely linked to the seasonality of the primary producers [3]. These systems are among the most susceptible to global climate change, but the knowledge base for Arctic benthic marine communities is slim. Near-shore, benthic communities are dynamic 
coastal ecosystems and can be heavily impacted by climate change as freshwater input, especially as the magnitude of ice sheet melt, snowpack extent and thickness, and other environmental factors change. Reduction in sea ice, increased seawater temperatures, and decreased $\mathrm{pH}$ levels have been recorded in recent years throughout the Arctic and these changes have direct impacts on the biotic communities [4,5]. Macroalgae communities are restricted by sea ice cover [6], but persist in the winter months and provide food when other primary producers (phytoplankton) are absent [7]. Therefore, any detrimental effects on these communities will be translated to secondary producers in the community. The rapid change we predict for Arctic environments calls for a comprehensive understanding of both environmental and ecological dynamics that structure benthic marine communities for the whole Arctic, where the effects of climate change are anticipated to be accelerated [8].

Arctic algal communities are often dominated by kelps, which structure marine communities worldwide $[9,10]$. Within Svalbard's macroalgae communities, the greatest biomass is found in shallow habitats (1-5 m), dominated by annual and pseudo-perennial species, and mass decreases with depth where perennial species abound [11]. Kelp beds are punctuated by rhodolith communities in the northeast Atlantic, which persist in more wave-sheltered, herbivore-dominated habitats along the coastlines [12]. North Atlantic kelps are stipitate and form short canopies often below the water line, in contrast to the larger canopy species that span the water column in other regions of the world (Macrocystis pyrifera [9]). However, increased water temperatures have the potential to affect population persistence and distribution of these species [13] and other dominant species in Europe are currently experiencing range restrictions in southern habitats which are projected to continue northward [14-16]. Already new species are being found and some have disappeared from the sublittoral in Svalbard [17]. In the southwest corner of Greenland, the most abundant kelp species are currently Laminaria solidungula J. Agardh, Alaria esculenta (Linnaeus) Greville, Saccharina longicruris (Bachelot de Pylaie) Kuntze, and Agarum clathratum Dumortier. In the study region, S. longicruris is the primary canopy-forming species, while A. clathratum and other chemically defended Phaeophytes can be found in other algal-dominated habitats [18-20]. Though marine angiosperms increase biomass turnover under warmer ocean conditions in Greenland [21], many polar species may respond poorly [16] and this will likely impact the local ecology of marine systems.

Marine communities supported by seaweeds and marine angiosperms are poorly understood in this region [22]. The polar flora are less diverse than other regions of the world [23] but we know they can greatly influence the communities they live in or structure [24,25]. Arctic kelp habitats are generally found on rocky coastlines, in low-sediment environments, down to $\sim 40 \mathrm{~m}$ depth depending on the region $[6,26]$. In Arctic communities, some herbivores rely on a dominant kelp, L. solindungula, for organic carbon in polar communities [24], and high carbon demand of the macrozoobenthos in Greenland [27] indicate this is likely to be true for most Arctic regions. Kelp forests further modify their habitat by regulating the $\mathrm{pH}$ in the water column during the Arctic day, where $24 \mathrm{~h}$ of daylight can lead to $0.15 \mathrm{pH}$ increase in surrounding water [28]. The mosaics of $\mathrm{pH}$ found within the forest itself may provide refuge for vulnerable calcifying species into the future [28,29]. Furthermore, food consumption is important in species (calcifier) resilience under ocean acidification scenarios [30], so if these habitats have the potential to persevere through climate change, so do their consumers.

Though most fleshy algal species do not show negative responses to high $p \mathrm{CO}_{2}$ (summarised in [31]), calcifying algae generally have a negative response (summarised in [32,33]). In the shallow Arctic marine environment, the nongeniculate coralline algae are some of the most prominent reef builders [34,35]. Corallines structure reef habitats in both crustose reef flats (Alaskan Arctic [36]) and in large free-living forms (rhodoliths or mäerl beds) (North Atlantic [37,38]) are biodiversity hotspots [36-38]. Dissolution of calcifying organisms is concerning in the Arctic. Jiang et al. [39] provide evidence that aragonite (one of the most common calcium carbonate minerals) saturation levels are low in Arctic Alaskan waters. A species of mäerl common to the North Atlantic, Lithothamnion 
glaciale Kjellman, has net loss in mass in low-salinity environments that reflects high input of glacial melt water [18], and net dissolution in high $\mathrm{pCO}_{2}$ environments [40]. Furthermore, kelp forests and coralline algae habitats are important for carbon storage in the marine environments (blue carbon repositories [40,41]), and decreased production or dissolution of calcified algae has the potential to reduce carbon burial in the marine Arctic. Carbonate $\left(\mathrm{CaCO}_{3}\right)$, fixed by coralline algae, is especially important for carbon burial worldwide [42], and although primary production and calcification rates are low in Clathromorphum sp. beds around Nuuk, Greenland [18], they likely represent a significant carbonate repository in the Arctic as a whole. Under ongoing climate change, coralline habitats are highly vulnerable, and the potential to lose ecosystem services, which have not been previously assessed in these regions, is high.

Coralline algae in Greenland were first described by Rink [43] as coralline crusts underlying kelp forests in western Greenland. These communities are thought to directly or indirectly compete with kelp community settlement depending on the flux of terrestrial humic substances [44], though they are generally described simply as benthic cover in urchin barrens [10]. Rhodolith beds persist in the Alaskan, Canadian, and Norwegian Arctic, and faunal communities are dominated by echinoderms, general grazers that have been hypothesized to prevent kelp dominance [37,45]. Rhodolith beds off Svalbard have high densities of bryozoans, polychaetes, molluscs, and crustaceans, but group dominance depends on location and the frequency of hollow versus nucleated rhodoliths [38]. In these systems, the structuring macroalgae do not provide direct food subsidies but host a complex food web where a high proportion of the fauna feed off particulate organic matter [46,47], and herbivores, predators, and scavengers are less frequent. Coralline algae habitats are prominent around the coastline of Greenland and reach deep depths of 50 to $77 \mathrm{~m}$ [48]. In southwestern Greenland, in the vicinity of Nuuk, coralline algae communities (rhodolith beds) are formed by Clathromorphum sp. [18,19,48], a sister species to Clathromorphum compactum [49].

The aim of this study was to describe the biodiversity of kelp forests, a group of seaweed that may be resilient to climate change, and rhodolith beds which may be more vulnerable to climate change, in southwestern Greenland. Surveys were completed at three different scales (macroflora and fauna, benthic cover, and interstitial communities) and the importance of organic and inorganic composition of the dominant rhodolith species, Clathromorphum sp., and living rhodoliths, to the biodiversity of rhodolith beds was determined. Finally, we quantified the cover of coralline algae, both crustose coralline algae (CCA) and rhodoliths, and density of kelp in each habitat to see how pervasive both are, even when they are not the dominant autotroph. The importance of corallines in Arctic marine communities is further inferred by investigating carbonate reservoirs in rhodolith beds. These data can be used as a baseline for monitoring present and future changes in marine communities.

\section{Materials and Methods}

\subsection{Field Work}

Research took place within the Akia Peninsula, the seaward islands of Godthåbsfjord, and Kobbefjord where fjord habitats meet the marine environment (Figure 1), from late July to late August 2016. Dive sites were found using local knowledge of the region from researchers at the Greenland Institute of Natural Resources (GINR) and drop camera observations [19]. Rhodolith beds $(\mathrm{n}=4)$ dominated by Clathromorphum sp., a sister species to Clathromorphum compactum [49], were generally located in interisland channels where the current is high (Figure 1, Table 1). Kelp forests $(n=4)$ are found in sediment-hard bottom habitats (here sediment includes a range of grain sizes from sand to glacial silt), near Nuuk or within the Akia Peninsula down to $10 \mathrm{~m}$ depth (Figure 1, Table 1). All surveys were conducted using SCUBA by two observers during slack tide. 


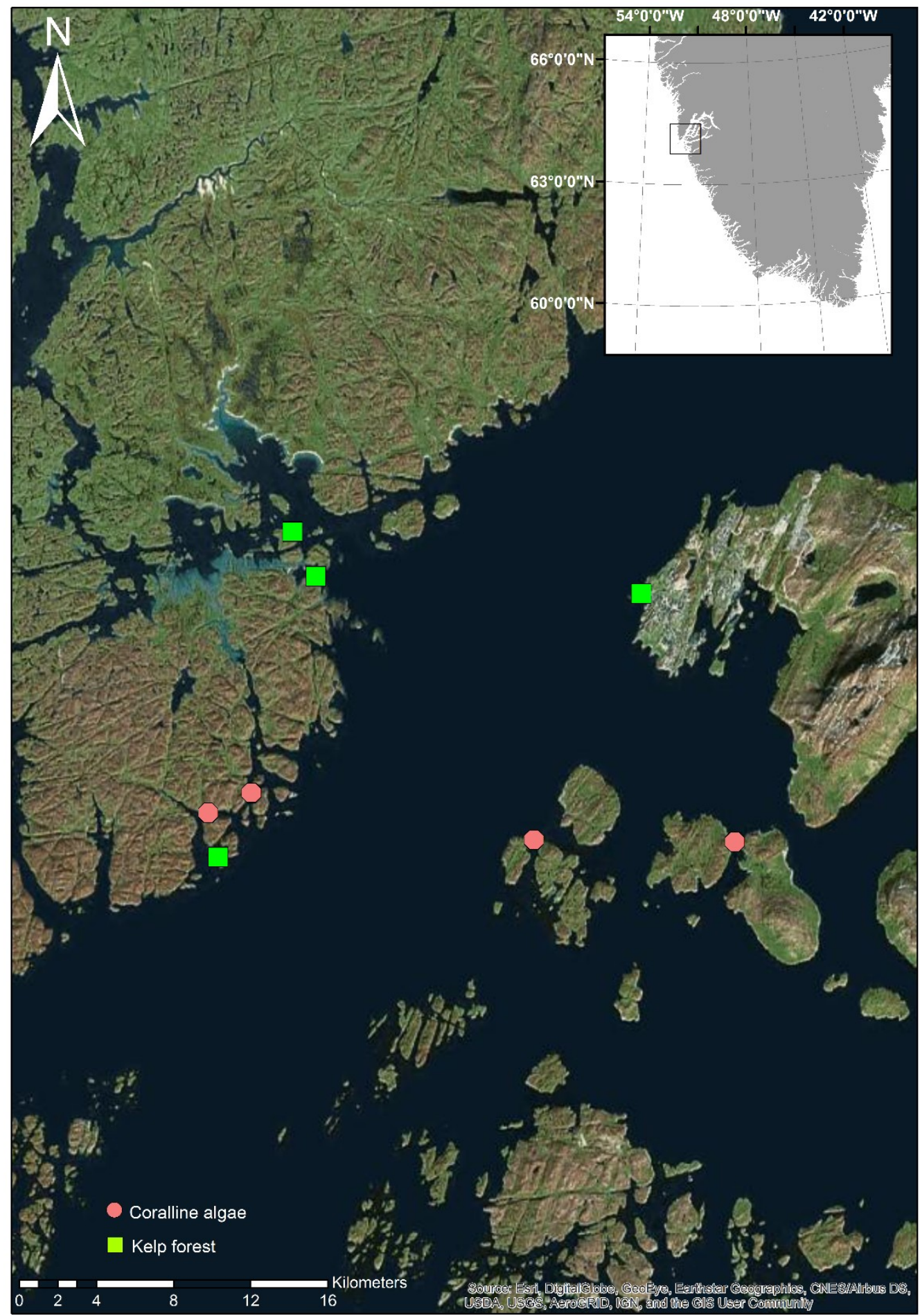

Figure 1. Map of the research area (WGS 1984 Web Mercator Auxiliary Projection) around the Akia peninsula and the seaward islands near Nuuk, with an inset referencing the location within Greenland. Green squares indicate kelp forest habitats and pink circles indicate rhodolith habitats that were sampled.

Community surveys were undertaken at three scales. First, a $30 \times 1 \mathrm{~m}$ swath survey of the habitat was done at each site, where one observer counted the number of each kelp species on the swath (primarily S. longicruris or A. clathratum), and the other took a video transect with a DSLR camera (Nikon D800, Nikkor 20 mm f/1.8 lens, Ikelite 200FL Underwater TTL Housing, and $2 \times$ Ikelite DS161 
strobes) swimming at a speed of $1 \mathrm{~m} \cdot \mathrm{s}^{-1}$. Second, along each swath ten $2500 \mathrm{~cm}{ }^{2}$ photo-quadrats were taken of the benthos at random meter marks using the DSLR camera and a $50 \times 50 \mathrm{~cm}$ PVC quadrat. Third, five $200 \mathrm{~cm}^{3}$ benthic grabs of either sediment (kelp forest) or rhodolith beds were taken with a PVC core ( $8 \mathrm{~cm}$ diameter, $4 \mathrm{~cm}$ depth) and placed in sample bags underwater which allowed them to mix, preventing identification of stratification in biodiversity throughout each sample. All samples were kept in ambient seawater during transport back to the GINR (duration $\sim 1 \mathrm{~h}$ ).

Table 1. Descriptive information of all dive sites including habitat type, qualitative assessment of sedimentation level (high, medium, and low), GPS coordinates (degrees minutes seconds), and average depth of site at slack tide (m).

\begin{tabular}{cccccc}
\hline Site Name & Habitat & Sediment Level & Latitude & Longitude & Depth (m) \\
\hline Colony Bay & kelp & Medium & $64^{\circ} 10^{\prime} 34.76^{\prime \prime} \mathrm{N}$ & $51^{\circ} 44^{\prime} 58.57^{\prime \prime} \mathrm{W}$ & 9.1 \\
Site 153 & kelp & High & $64^{\circ} 10^{\prime} 45.24^{\prime \prime} \mathrm{N}$ & $51^{\circ} 53^{\prime} 27.61^{\prime \prime} \mathrm{W}$ & 5.2 \\
Site 4 & kelp & Low & $64^{\circ} 7^{\prime} 19.96^{\prime \prime} \mathrm{N}$ & $51^{\circ} 56^{\prime} 49.34^{\prime \prime} \mathrm{W}$ & 6.4 \\
Bird Island & kelp & Medium & $64^{\circ} 11^{\prime} 16.91^{\prime \prime} \mathrm{N}$ & $51^{\circ} 54^{\prime} 24.52^{\prime \prime} \mathrm{W}$ & 8.7 \\
Site 124 & rhodolith & Low & $64^{\circ} 8^{\prime} 17.37^{\prime \prime} \mathrm{N}$ & $51^{\circ} 55^{\prime} 55.62^{\prime \prime} \mathrm{W}$ & 4.6 \\
Site 121 & rhodolith & Low & $64^{\circ} 8^{\prime} 3.11^{\prime \prime} \mathrm{N}$ & $51^{\circ} 57^{\prime} 5.48^{\prime \prime} \mathrm{W}$ & 5.2 \\
Site 14 & rhodolith & Low & $64^{\circ} 7^{\prime} 38.51^{\prime \prime} \mathrm{N}$ & $51^{\circ} 42^{\prime} 21.30^{\prime \prime} \mathrm{W}$ & 5.4 \\
Site 160 & rhodolith & Low & $64^{\circ} 7^{\prime} 39.31^{\prime \prime} \mathrm{N}$ & $51^{\circ} 47^{\prime} 56.82^{\prime \prime} \mathrm{W}$ & 5.3 \\
\hline
\end{tabular}

\subsection{Laboratory Analysis}

All grab samples were kept in a cold room $\left(2{ }^{\circ} \mathrm{C}\right)$ at the GINR until they were processed $(\sim 2-4 \mathrm{~h})$. Samples were sorted in a tray with seawater to determine the abundance and diversity of fauna in the sediment or rhodolith matrix. There is no specific key to the taxonomy of Greenlandic species, but community members were identified to the lowest taxonomic resolution possible using a key for northwestern Europe [50]. After extracting all fauna from grab collections, representative specimens for each taxonomic unit were preserved in alcohol for transport back to the University of Glasgow under refrigerated conditions of $4{ }^{\circ} \mathrm{C}$. The identification of faunal specimens was validated by an independent observer prior to final data analysis. Functional group of each taxonomic unit was identified when possible to autotroph, grazer, deposit feeder, detritivore, filter feeder, suspension feeder, omnivore, predator, and mixed or unknown to qualitatively assess the different community assemblages.

After picking fauna from collections, all sediment and rhodoliths were drained and wet weight was measured. Rhodoliths were categorised as either 'live' or 'dead'; live individuals had pigmentation and very little fouling on the exterior while dead individuals lacked pigmentation and were covered in epiphytes. This distinction was made to determine whether rhodoliths are important as a primary producer (live) or solely as a three-dimensional matrix for species to inhabit (both live and dead). All rhodolith samples from each grab were dried at $30{ }^{\circ} \mathrm{C}$ dry weight (DW) and taken back to the University of Glasgow to determine the amount of $\mathrm{CaCO}_{3} \mathrm{~m}^{-3}$ in rhodolith habitats. 'Live' samples ( $\mathrm{n}=2$ per site when possible) and 'dead' samples $(\mathrm{n}=1$ per site when possible) were dried at $100{ }^{\circ} \mathrm{C}$ to evaporate water $\left(\mathrm{DW}_{100}\right)$, weighed, and then heated to $550{ }^{\circ} \mathrm{C}$ to burn off organic material $\left(\mathrm{DW}_{550}\right)$. Following this, all samples were dissolved in $\mathrm{HCl}$ over a $24 \mathrm{~h}$ period, rinsed with deionised water, and then dried again at $100{ }^{\circ} \mathrm{C}$ to determine carbonate contribution to dry weight $\left(\mathrm{DW}_{\mathrm{CACO} 3}\right)$. Organic content and $\mathrm{CaCO}_{3}$ content were then calculated using Equations (1) and (2) as a percentage of dry weight (DW). These values were then used to estimate $\mathrm{g} \mathrm{CaCO}_{3} \cdot \mathrm{m}^{-3}$ in each bed using Equation (3).

$$
\begin{gathered}
\% \text { Organic content }=\left(\left(\mathrm{DW}_{100}-\mathrm{DW}_{550}\right) / \mathrm{DW}_{100}\right) \times 100 \\
\% \mathrm{CaCO}_{3} \text { content }=\left(\left(\mathrm{DW}_{550}-\mathrm{DW}_{\mathrm{CACO} 3}\right) / \mathrm{DW}_{100}\right) \times 100 \\
\mathrm{~g} \mathrm{CaCO}_{3} \mathrm{~m}^{-3}=\left(\mathrm{CaCO}_{3} \times \mathrm{DW}_{100}\right) / 0.2 \mathrm{~m}^{3}
\end{gathered}
$$




\subsection{Video and Image Analysis}

All video surveys were watched at 'slower' speed ( $\sim .25 \times$ step rate) in VLC media player (v 2.2.1, VideoLAN, Paris, France) to count the number of both sessile and mobile macro fauna within the swath. Fish were very rare in these surveys, so there was little risk of counting these individuals twice. The percent cover of coralline algae within the swath was estimated for both habitat types, CCA in kelp forests and both CCA and rhodoliths in rhodolith beds. In photo-quadrats, 40 random points were placed on each image within the quadrat and species were identified to the lowest taxonomic resolution. Some species were easy to identify but others, like the filamentous algae-forming turf communities, were grouped. These data were used to estimate percent cover of each taxonomic unit, in each habitat, with the image analysis software CPCe [51]. The abundance of species in each photo-quadrat was quantified for diversity analysis of benthic communities.

\subsection{Statistical Analysis}

To determine the diversity of each habitat, species richness (S), Shannon diversity $\left(\mathrm{H}^{\prime}\right)$, and species evenness (J) were calculated using abundance data (to the lowest taxonomic unit) in the vegan package in R [52] with each type of survey data (swath, photo-quadrat and grab). A general linear model (GLM) was used to compare differences in biological communities across habitats (kelp or rhodolith) at all scales using SPSS (ver 24, IBM, Armonk, NY, USA). The species identification in this study, while reliable, could not separate important taxa like the polychaetes, which have a diverse array of feeding modes. As a result, all analysis of functional diversity in these communities was not statistically evaluated but is discussed.

The community composition of each site was compared at each scale (swath survey, photo-quadrat, and grab) using PRIMER (v6 [53]). All species abundance data from swaths and grabs were fourth-root transformed, subsequently non-parametric multidimensional scaling (nMDS) with Euclidean distances was performed, followed by an analysis of similarity (ANOSIM) to assess similarity of communities in each habitat. The composition of the benthic communities, identified using random point counts (RPC) in photo-quadrats (mono-layered structure [54]), were compared using nMDS with Euclidean distances of untransformed percent cover data, followed by an ANOSIM. A SIMPER distance-based analysis was then used to investigate which species drove similarity, and differences, between habitats at each survey scale.

To investigate the importance of coralline algae in marine communities, a Student's $t$ test was used to compare kelp density $\mathrm{m}^{-2}$ and estimated percent cover of coralline algae from swath surveys in each habitat (SPSS, ver 24, IBM). The organic and carbonate composition of live, and dead, rhodoliths were then compared across sites and grabs, using a GLM with the covariate 'live' (alive or dead; SPSS, ver 24, IBM). Pearson correlations were used to determine whether the percentage of living rhodoliths significantly affected the species richness and diversity of the community (SPSS, ver 24, IBM).

\section{Results}

\subsection{Habitat Diversity}

Rhodolith beds were predominantly covered by the free-living coralline algae, shells, stones and bedrock with CCA (Figure 2a), and often included detrital kelp. Kelp forest communities are founded on bedrock, boulders (both covered in CCA), sediment (Figure 2b), and can include marine detritus (fragmented algae from subtidal and intertidal habitats). In locations with higher sediment cover such as Colony Bay or Bird Island (Figure 1, Table 1), kelp were often attached to small rocks and shell, while at sites 4 and 153, kelp was predominantly attached to bedrock and boulders. Notably, no juvenile kelps were recorded in any survey. A range of fauna was found in kelp and coralline algae habitats (described from all survey methods), many of which were found in both habitat types (Table 2). The S, $\mathrm{H}^{\prime}$, and $\mathrm{J}$ of swath surveys were not significantly different between rhodolith beds and kelp forests $\left(F_{\mathrm{df1}}=0.977,1.407,0.616 ; p=0.368,0.289,0.468\right.$, respectively; Table 3$)$. The biological communities 
in photo-quadrats had significantly higher $\mathrm{S}, \mathrm{H}^{\prime}$, and $\mathrm{J}$ in kelp forest habitats than rhodolith habitats $\left(\mathrm{F}_{\mathrm{df1}}=7.791,6.92,5.414 ; p<0.007,0.01,0.023\right.$, respectively; Table 3). Grab samples from rhodolith beds had significantly greater $\mathrm{S}, \mathrm{H}^{\prime}$, and $\mathrm{J}$ than grabs from kelp forest habitats $\left(\mathrm{F}_{\mathrm{df1}}=70.676,39.556,25.279\right.$, respectively; $p<0.000$ for all; Table 3 ).

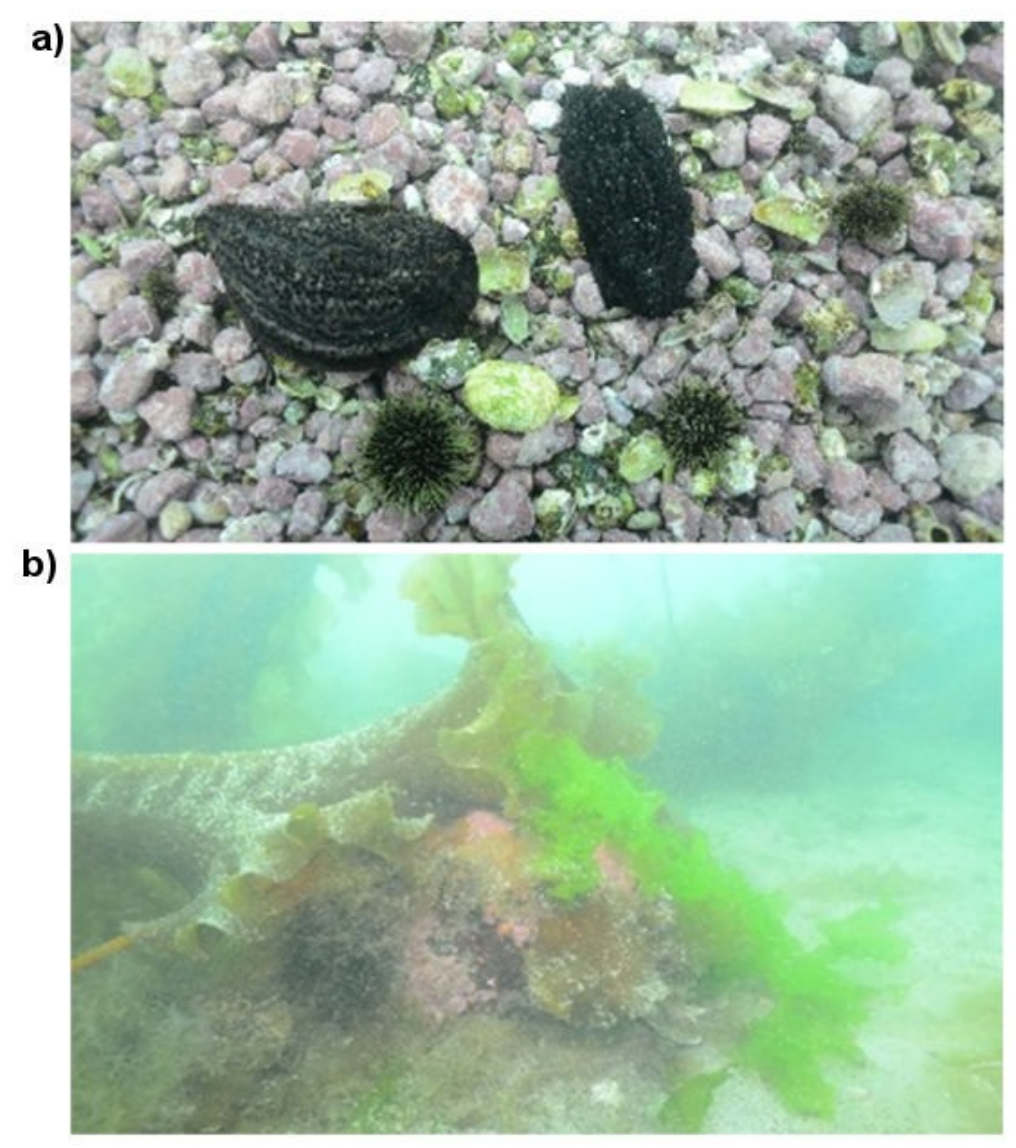

Figure 2. (a) Rhodolith beds are dominated by the free-living coralline algae and include shells, stones, and some bedrock covered in CCA, while (b) kelp forests are found on bedrock, boulders, shell, or stones often with greater levels of sediment cover. 
Table 2. List of species grouped by phylum from all kelp and rhodolith beds in the Nuuk region with a grey-scale indication of SACFOR abundance scale [55] in each habitat; white indicates no record, light-grey present, medium-grey is frequent, dark-grey is common, and black indicates abundant. Species identification was done to the lowest taxonomic unit possible in lab (preserved in ethanol) and with photographic records. Some species are grouped such as the filamentous algae and micrograzers because higher resolution was not possible. All taxonomic units include their feeding method: (A) autotroph, (Dep) deposit feeder, (Det) detritivore, (F) filter feeder, $(\mathrm{G})$ grazer, $(\mathrm{O})$ omnivore, $(\mathrm{P})$ predator, $(\mathrm{S})$ suspension feeder, and $(\mathrm{U})$ unknown.

\begin{tabular}{|c|c|c|c|c|c|c|}
\hline & Grabs & & Surveys & & Quadrats & \\
\hline & Rhodolith Bed & Kelp Forest & Rhodolith Bed & Kelp Forest & Rhodolith Bed & Kelp Forest \\
\hline Algae & & & & & & \\
\hline filamentous algae (A) & & & & & & \\
\hline $\begin{array}{ll}\text { Rhodophyta } & \text { Rhodolith (A) }\end{array}$ & & & & & & \\
\hline $\begin{array}{r}\text { Knodolith }(A) \\
\text { CCA * (A) }\end{array}$ & & & & & & \\
\hline $\begin{array}{r}\text { Porphyra spp. (A) } \\
\text { Palmaria palmato (A) }\end{array}$ & & & & & & \\
\hline Palmaria palmata (A) & & & & & & \\
\hline kelp drift (A) & & & & & & \\
\hline Saccharina longicruis (A) & & & & & & \\
\hline Agarum clathratum (A) & & & & & & \\
\hline Alaria esculenta (A) & & & & & & \\
\hline Desmarestia aculeata (A) & & & & & & \\
\hline Chlorophyta & & & & & & \\
\hline Ulva spp. (A) & & & & & & \\
\hline$\frac{\text { Animalia }}{\text { Porifera }}$ & & & & & & \\
\hline Haliclona sp. (F, S) & & & & & & \\
\hline Mycale sp. (F, S) & & & & & & \\
\hline Myxilla sp. (F, S) & & & & & & \\
\hline Reniera rufescens (F, S) & & & & & & \\
\hline Mollusca & & & & & & \\
\hline Class Bivalvia & & & & & & \\
\hline Hiatella arctica $(\mathrm{F})$ & & & & & & \\
\hline Mytilus spp. (F) & & & & & & \\
\hline Macoma calcarea (Dep) & & & & & & \\
\hline Enписиla tenuis (Det) & & & & & & \\
\hline Chlamys islandica $(\mathrm{F})$ & & & & & & \\
\hline Class Gastropoda & & & & & & \\
\hline Siphonodentalium lobatum (Dep) & & & & & & \\
\hline Gibbula magus (G, Dep) & & & & & & \\
\hline Gibbula umbilicalis (G, Dep) & & & & & & \\
\hline Littorina saxatilis $(\mathrm{G})$ & & & & & & \\
\hline Cryptonatica affinis (P) & & & & & & \\
\hline Natica clausa $(\mathrm{P})$ & & & & & & \\
\hline Margarites helicinus (G, Dep) & & & & & & \\
\hline Margarites sp. (G, Dep) & & & & & & \\
\hline
\end{tabular}


Table 2. Cont

\begin{tabular}{|c|c|c|c|c|c|c|}
\hline \multirow{5}{*}{$\begin{array}{r} \\
\text { Tonicella rubra }(\mathrm{G}) \\
\text { Tectura testudinalis }(\mathrm{G}) \\
\text { Dendronotus frondosus }(\mathrm{P}) \\
\text { Echinodermata }\end{array}$} & \multirow{2}{*}{$\begin{array}{c}\text { Grabs } \\
\text { Rhodolith Bed }\end{array}$} & & \multicolumn{2}{|l|}{ Surveys } & \multicolumn{2}{|l|}{ Quadrats } \\
\hline & & Kelp Forest & Rhodolith Bed & Kelp Forest & Rhodolith Bed & Kelp Fores \\
\hline & & & & & & \\
\hline & & & & & & \\
\hline & & & & & & \\
\hline Asterias rubens (S) & & & & & & \\
\hline Psolus fabricii (S) & & & & & & \\
\hline Strongylocentrotus droebachiensis (P, Dep) & & & & & & \\
\hline Ophiura sarsi (S) & & & & & & \\
\hline Leptasterias polaris (S) & & & & & & \\
\hline Sargatiogeton laceratus (S) & & & & & & \\
\hline Сucumaria frondosa (S) & & & & & & \\
\hline Annelida & & & & & & \\
\hline Gattyana cirrosa $(\mathrm{U})$ & & & & & & \\
\hline Euchurian sp. (U) & & & & & & \\
\hline Order Phoronida (F) & & & & & & \\
\hline Phyllodoce groenlandica $(\mathrm{P})$ & & & & & & \\
\hline Nipponnemertes pulchra $(\mathrm{U})$ & & & & & & \\
\hline Arthropoda & & & & & & \\
\hline Semibalanus balanoides $(\mathrm{F})$ & & & & & & \\
\hline Order Amphipoda (F, Det, S, P) & & & & & & \\
\hline Hyas coarctatus $(\mathrm{O})$ & & & & & & \\
\hline Weyprechtia pinguis (U) & & & & & & \\
\hline Acanthonotozoma inflatum (U) & & & & & & \\
\hline Calanus sp. (U) & & & & & & \\
\hline Order Mysida (U) & & & & & & \\
\hline unknown micrograzers $(G)$ & & & & & & \\
\hline Bryozoa & & & & & & \\
\hline Cellaria sp. (F) & & & & & & \\
\hline Bolinopsis infundibulum $(\mathrm{P})$ & & & & & & \\
\hline (1) & & & & & & \\
\hline $\begin{array}{r}\text { Gadus morhua }(\mathrm{P}) \\
\text { (n) }\end{array}$ & & & & & & \\
\hline $\begin{array}{r}\text { Leptocottus armatus }(\mathrm{P}) \\
\text { Myoxocephalus scorpius }(\mathrm{P})\end{array}$ & & & & & & \\
\hline
\end{tabular}


Table 3. Sample size (n), species richness (S), diversity (Shannon, $\mathrm{H}^{\prime}$ ), and evenness (J) for each survey at all eight sites (mean \pm SE for all surveys with $\mathrm{n}>1$ ).

\begin{tabular}{|c|c|c|c|c|c|c|c|c|c|c|c|c|}
\hline & & $\begin{array}{l}\text { Swath } \\
\text { Survey }\end{array}$ & & & & Photo-Quadr & & & & $\begin{array}{c}\text { Benthic } \\
\text { Grabs }\end{array}$ & & \\
\hline Habitat & $\mathrm{n}$ & $\mathrm{s}$ & $\mathbf{H}^{\prime}$ & $J$ & $\mathrm{n}$ & $S$ & $\mathrm{H}^{\prime}$ & $\mathbf{J}$ & $\mathrm{n}$ & $S$ & $\mathbf{H}^{\prime}$ & $\mathbf{J}$ \\
\hline \multicolumn{13}{|l|}{ Kelp forest } \\
\hline Colony Bay & 1 & 4 & 0.82 & 0.59 & 8 & $2.5 \pm 0.19$ & $0.66 \pm 0.08$ & $0.74 \pm 0.08$ & 5 & $6.6 \pm 0.75$ & $1.23 \pm 0.11$ & $0.66 \pm 0.03$ \\
\hline Site 153 & 1 & 12 & 1.66 & 0.67 & 9 & $4.33 \pm 0.67$ & $1.01 \pm 0.13$ & $0.76 \pm 0.04$ & 5 & $5 \pm 0.63$ & $1.16 \pm 0.06$ & $0.75 \pm 0.04$ \\
\hline Site 4 & 1 & 8 & 1.42 & 0.68 & 10 & $5.25 \pm 0.49$ & $1.37 \pm 0.11$ & $0.85 \pm 0.03$ & 5 & $8.4 \pm 0.68$ & $1.51 \pm 0.18$ & $0.71 \pm 0.07$ \\
\hline Bird Island & 1 & 1 & 0 & 0 & 5 & $3 \pm 0.45$ & $0.62 \pm 0.13$ & $0.59 \pm 0.06$ & 5 & $4.8 \pm 0.73$ & $1.15 \pm 0.19$ & $0.74 \pm 0.05$ \\
\hline Average & & $6.25 \pm 4.79$ & $0.96 \pm 0.36$ & $0.49 \pm 0.33$ & & $4.03 \pm 1.85$ & $1 \pm 0.45$ & $0.76 \pm 0.16$ & & $6.2 \pm 2.07$ & $1.26 \pm 0.33$ & $0.71 \pm 0.11$ \\
\hline \multicolumn{13}{|l|}{ Rhodolith Bed } \\
\hline Site 124 & 1 & 4 & 0.17 & 0.12 & 10 & $3.2 \pm 0.39$ & $0.69 \pm 0.14$ & $0.58 \pm 0.08$ & 5 & $9.6 \pm 1.69$ & $2.06 \pm 0.14$ & $0.93 \pm 0.01$ \\
\hline Site 121 & 1 & 6 & 0.71 & 0.4 & 9 & $2.67 \pm 0.24$ & $0.65 \pm 0.1$ & $0.68 \pm 0.08$ & 5 & $11.8 \pm 0.8$ & $2.15 \pm 0.1$ & $0.87 \pm 0.02$ \\
\hline Site 14 & 1 & 5 & 0.11 & 0.07 & 10 & $3.7 \pm 0.3$ & $0.88 \pm 0.06$ & $0.69 \pm 0.04$ & 4 & $14 \pm 0.71$ & $2.07 \pm 0.09$ & $0.78 \pm 0.04$ \\
\hline Site 160 & 1 & 4 & 0.17 & 0.12 & 10 & $3.36 \pm 0.2$ & $0.78 \pm 0.7$ & $0.65 \pm 0.04$ & 4 & $10.25 \pm 1.31$ & $2 \pm 0.17$ & $0.87 \pm 0.05$ \\
\hline Average & & $4.75 \pm 0.96$ & $0.26 \pm 0.18$ & $0.18 \pm 0.15$ & & $3.25 \pm 0.95$ & $0.75 \pm 0.31$ & $0.65 \pm 0.19$ & & $11.33 \pm 2.93$ & $2.07 \pm 0.26$ & $0.87 \pm 0.08$ \\
\hline
\end{tabular}


The contribution of each functional group to surveys in both kelp forests and rhodolith beds fluctuated based on survey type (Table 4). In general, the greatest diversity of functional groups was found in grab samples (Table 4), especially from rhodolith beds, but many of the taxonomic groups were not identified to species level in these samples so individuals with unknown trophic placements were well represented in the data (Annelids and Arthropods; Table 2). Mixed feeders (Gastropoda and Arthropoda; Table 2) and autotrophs were the next richest groups, followed by grazers (Gastropoda) and filter feeders (Bivalvia and Annelida) in grab samples (Table 4). In swaths, 'mixed' and predator groups have the highest richness, which was driven by the large number of sponges, amphipods, and echinoderms (mixed) and fish (predators) that were counted in this type of survey (Table 2). Autotrophs were the next most abundant, followed by filter (Bivalvia and Arthropoda) and suspension feeders (Echinodermata; Tables 2 and 4). In photo-quadrats, autotrophs were the richest grouping, followed by filter feeders (Bivalvia, Bryozoa, and Arthropoda; Tables 2 and 4), suspension feeders (Echinodermata; Tables 2 and 4), and mixed feeders (Porifera and Echinodermata; Tables 2 and 4). Overall suspension, filter, and predatory feeders were the richest functional groups after autotrophs in these marine systems (Table 4).

Table 4. The trophic level of each taxonomic unit was identified and the contribution of each functional group to the whole community is expressed as a percentage of all species counted in each survey type in each habitat.

\begin{tabular}{ccccccc}
\hline Sample Method & Grabs & \multicolumn{3}{c}{ Swath } & \multicolumn{2}{c}{ Photo-Quadrat } \\
\hline & Rhodolith & Kelp & Rhodolith & Kelp & Rhodolith & Kelp \\
Autotroph & $12 \%$ & $4 \%$ & $30 \%$ & $16 \%$ & $75 \%$ & $63 \%$ \\
Filter feeder & $12 \%$ & $12 \%$ & $10 \%$ & $16 \%$ & $8 \%$ & $13 \%$ \\
Deposit feeder & $6 \%$ & $8 \%$ & $0 \%$ & $0 \%$ & $0 \%$ & $0 \%$ \\
Detritivore & $3 \%$ & $4 \%$ & $0 \%$ & $0 \%$ & $0 \%$ & $0 \%$ \\
Suspension feeder & $12 \%$ & $8 \%$ & $10 \%$ & $11 \%$ & $0 \%$ & $6 \%$ \\
Grazer & $9 \%$ & $4 \%$ & $0 \%$ & $0 \%$ & $0 \%$ & $0 \%$ \\
Omnivore & $3 \%$ & $0 \%$ & $0 \%$ & $0 \%$ & $0 \%$ & $0 \%$ \\
Predator & $9 \%$ & $16 \%$ & $30 \%$ & $26 \%$ & $0 \%$ & $6 \%$ \\
Mixed & $18 \%$ & $20 \%$ & $20 \%$ & $32 \%$ & $17 \%$ & $13 \%$ \\
Unknown & $15 \%$ & $24 \%$ & $0 \%$ & $0 \%$ & $0 \%$ & $0 \%$ \\
\hline
\end{tabular}

Using multivariate analyses to further describe community composition, we found that the abundance of kelp, mobile, and sessile fauna on swath surveys had greater similarity within habitat type than across habitats ( $R=0.604, p=2.9 \%$; Figure $3 a$ ) which was driven by the greater abundance of urchins within rhodolith habitats and sea cucumbers within kelp forests (Table S1). Species assemblages in kelp forest surveys were more unique to site (Figure 3a) which may be due to greater variation in sediment level across site (Table 1). Unfortunately, some photo-quadrats were not analysed because the turbidity of the water column and bad lighting prevented species identification (mostly in kelp habitats). Therefore, sample size at each site ranged between 5 and 10 photographs in kelp forests and 9 and 10 photographs in rhodolith beds (Table 3). The benthic community and substrate of each habitat type had greater similarity within habitats than across $(R=0.565, p=0.1 \%$; Figure $3 b)$. Habitats have many species in common (for instance, the urchin Strongylocentrotus droebachiensis), but the higher percent cover of coralline algae and A. clathratum in rhodolith beds, rather than sediment and S. longicruris in kelp forests, drove major differences between the habitats (Table S2). Not all grabs were intact after transport to the laboratory due to adverse weather conditions or sample bag failure ( $n=4-5$ per site; Table 3$)$, and stratification of organisms within a grab could not be evaluated. Grabs resulted in the most diverse communities (fauna only) and habitats were very distinct $(\mathrm{R}=0.22$, $p=0.1 \%$; Figure $3 c$ ), largely due to high abundance of unique crustaceans and molluscs in kelp forests, which had a sediment matrix (Table S3). Grabs from rhodolith beds (including live and dead rhodoliths) had higher abundance of worms, echinoderms, some crustaceans, and mollusks, including Semibalanus balanoides and the top shells (Table S3). 

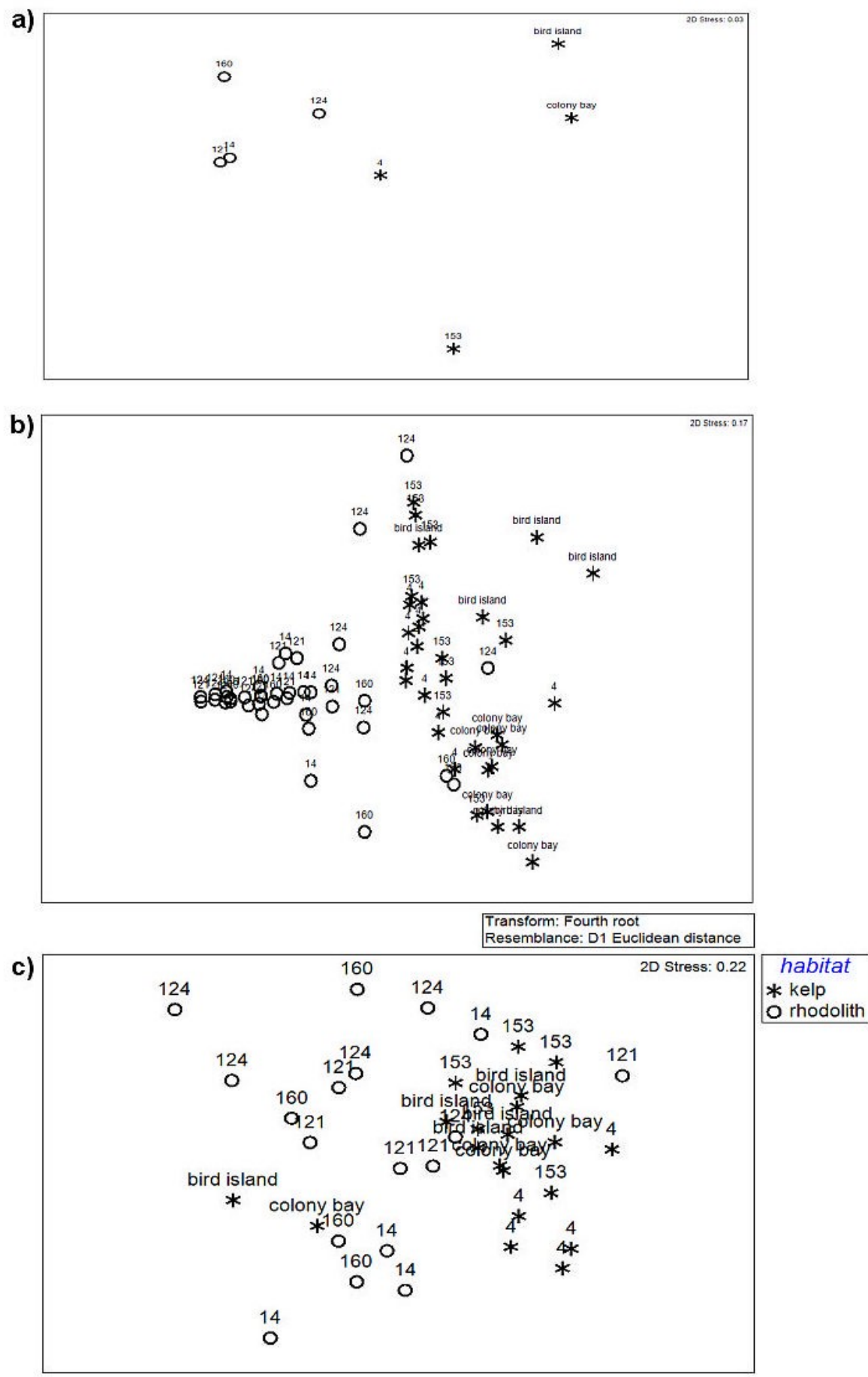

Figure 3. Faunal communities in kelp forest and rhodolith bed habitats are clustered using non-parametric multidimensional scaling (nMDS) plots with Euclidean distances for data from (a) swath surveys ( $\mathrm{n}=4$ per habitat type) where rhodolith communities are more alike than kelp forests, (b) the benthic cover of marine communities (photo-quadrats, $n=5-10$ depending on site), most similar within habitat type, and (c) the faunal communities of benthic grabs ( $n=5$ per site) which are distinct from each other, but show similarity within sites within habitats.

\subsection{Influence of Coralline Algae on Composition and Diversity of Habitats}

The percent cover of coralline algae, both CCA and rhodoliths, was significantly different between kelp and rhodolith beds $\left(\mathrm{T}_{\mathrm{df} 6}=-8.168\right.$, sig $(2$-tailed $\left.)=0.004\right)$, with an average of $18 \pm 10.1 \%$ cover of understory coralline algae in kelp beds in comparison to $100 \%$ cover of coralline algae 
in rhodolith beds. The density of kelps at each site was significantly higher in kelp forests $\left(\mathrm{T}_{\mathrm{df} 6}=8.717\right.$, sig (2-tailed) $=0.002$ ), with an average of $9.14 \pm 0.9 \mathrm{kelp} \mathrm{m}^{-2}$ in kelp forests (including A. clathratum, S. longicruris, and A. esculenta) versus $0.94 \pm 0.29$ A. clathratum $\mathrm{m}^{-2}$ in rhodolith beds. Findings show that coralline algae, in the form of rhodoliths, are a carbonate repository in Greenland, with an estimated range of 28.06 to $103.73 \mathrm{~g} \mathrm{CaCO}_{3} \mathrm{~m}^{-2}$. Live rhodoliths account for $90-95 \%$ of the rhodoliths in benthic grabs (Table 5). The GLM indicated that live rhodoliths had a higher percentage of organic material and carbonates within thallus material compared to dead rhodoliths, likely driven by differences at sites 121 and $160\left(\mathrm{GLM} \mathrm{F}_{\mathrm{df2}}=5.991, p<0.012 ;\right.$ Table 5). Additionally, there was variation (not statistically significant) in carbonate and organic composition of rhodoliths across sites, indicating that some sites have more nucleated rhodoliths than others $\left(\mathrm{GLM} \mathrm{F}_{\mathrm{df6}}=2.243, p<0.064\right.$; Table 5). There was no significant correlation between the percent of live rhodoliths in benthic grabs with the diversity of taxa present in rhodolith beds (Pearson Correlation -0.115 , sig (2-tailed) $=0.65$ ) or species richness (Pearson Correlation -0.126 , sig $(2$-tailed $)=0.619)$.

Table 5. Rhodolith attributes from benthic grabs at the four sites surveyed in the Nuuk region including average $\mathrm{DW}_{100}$ (dry weight) of live and dead rhodoliths, with \% live individuals indicated under site name, the average organic content in live and dead rhodoliths $\left(\% \mathrm{DW}_{550}\right)$, and the average carbonate content in live and dead rhodoliths (\% DW $\left.\mathrm{DaCO}_{3}\right)$. A calculation of total $\mathrm{CaCO}_{3} \mathrm{~m}^{-2}$ in rhodolith beds all values $\pm S E$.

\begin{tabular}{cccccc}
\hline Site & & $\mathbf{D W}_{\mathbf{1 0 0}}$ & \% DW $\mathbf{D W}_{\mathbf{5 5 0}}$ & \% DW $\mathbf{D W}_{\mathbf{C O}}$ & $\mathbf{C a C O}_{\mathbf{3}} \mathbf{( g ) \mathbf { ~ m } ^ { - 3 }}$ \\
\hline site 124 & dead & $9.55 \pm 4.24$ & $5.03 \pm 0.75$ & $40.6 \pm 19.7$ & $28.06 \pm 5.02$ \\
$95 \%$ & live & $214.56 \pm 43.91$ & $4.98 \pm 0.63$ & $34 \pm 9$ & \\
site 121 & dead & $32.63 \pm 8.73$ & $2.34 \pm 0.42$ & $61.9 \pm 15.9$ & $72.09 \pm 12.99$ \\
$90 \%$ & live & $288.49 \pm 24.24$ & $4.56 \pm 0.25$ & $52.3 \pm 7.3$ & \\
site 14 & dead & $18.44 \pm 8.9$ & $4.93 \pm 1.46$ & $43.2 \pm 18.9$ & $39.12 \pm 23.16$ \\
$92 \%$ & live & $211.18 \pm 37.98$ & $6.25 \pm 0.44$ & $79.6 \pm 15.5$ & \\
site 160 & dead & $30.53 \pm 20.48$ & $1.64 \pm 0.18$ & $48.8 \pm 34$ & $103.73 \pm 34.37$ \\
$93 \%$ & live & $420.89 \pm 59.74$ & $5.24 \pm 0.84$ & $54 \pm 17.4$ & \\
\hline
\end{tabular}

\section{Discussion}

This study contributes to the few descriptions of the ecology of shallow marine habitats in Greenland dominated by kelp and coralline algae. This baseline data is important because kelp and coralline algae are important ecosystem engineers which are threatened by ongoing changes to the ocean environment. Arctic systems may be especially vulnerable to changes such as increased ocean acidity and warming $[5,56]$, which are likely to impact many species assemblages, including those dominated by marine algae $[5,16,17]$. Coralline algae have high potential to respond negatively to acidified oceans (summarised in [32,33]) and low salinity [18]. In contrast, kelps can be a refuge from low $\mathrm{pH}[29]$ but some species respond poorly to increased temperatures (especially the greater frequency of marine heatwaves worldwide $[57,58]$ ) and low salinity [59]. The understanding of these marine communities in their present state, which this study provides, is a crucial baseline from which to measure future change.

\subsection{Kelp Versus Coralline Algal Habitats}

Algal-dominated habitats in Greenland are both important from an ecological and economical perspective, as they house a diverse array of species and functional groups that contribute to the marine and the terrestrial food webs [60]. Coralline algae are pervasive in these marine habitats, either dominating the rhodolith beds, or contributing significantly to cover of hard substrate in kelp forests [10]. Three scales of community surveys reveal differences in community diversity and functional groups, species richness, and evenness, and highlight the taxa that dominate the two types of seaweed habitat. Swath surveys targeting large mobile (fish and urchins) and sessile macro-fauna indicate no difference in the diversity, richness, or evenness of faunal communities when the dominant 
autotroph is coralline algae or kelp, and these groups are not mutually exclusive as crustose coralline algae were common in S. longicruris forests and A. clathratum was common in rhodolith beds. Jørgensbye and Halfar [48] previously noted the prevalence of $A$. clathratum in rhodolith beds during a survey of coralline algae around the coast of Greenland and the abundance of this chemically defended species is also noted in Canadian urchin barrens, where it thrives and facilitates the growth of understory algae species despite the large herbivore population [18]. Densities at sites in southwestern Greenland are lower than Canadian reports, with $\sim 1$ individual $\mathrm{m}^{-2}$ of rhodolith bed compared to $40-80 \%$ cover over urchin barrens in the Mingan Islands, northern Gulf of St. Lawrence [20]. Each autotroph houses distinct communities; the urchin S. droebachiensis (mixed feeder) was more than 20 times more abundant in rhodolith beds than kelp forests, and unique characters in this habitat include the predatory cnidarian Bolinopsis infundibulum and mollusc Dendronotus frondosus. The commercial fish Gadus morhua was only recorded in kelp forests, along with filter feeders like the sea cucumber Psolus fabricii. Nevertheless, G. morhua is often seen during dives in rhodolith beds, and the rarity of fish species on surveys indicates that a different type of survey methodology, such as the methods of Brand and Fischer [61], should be used to quantify these populations in the future. Overall, predators and autotrophs were the most abundant in swath surveys, followed by mixed trophic and filter feeders which might be expected from this survey which focused on larger flora on fauna.

Benthic cover of each seaweed habitat, examined in monolayer using photo-quadrats, highlight differences in substrate composition of each habitat corroborating kelp density and coralline algae cover estimates from swath surveys. The substrate in kelp forests was more diverse, or varied, than the 'monoculture' of rhodoliths found in coralline algae habitats, and these habitats had higher number of bottom-dwelling or sessile species. Many of the kelp forests had high-medium sediment levels (Table 1), likely due to the location at the mouth of a fjord abutted by multiple tidewater glaciers, but forests appeared stable and few were visited a previous year for maerl collections (bird island [18]). Unique species found within photo-quadrats from kelp sites were the filter-feeding bryozoan Cellaria sp., the Arctic staghorn sculpin (Gymnocanthus tricuspis), and multiple sponge taxa (identified to genus, Table 2). In rhodolith beds, commonly observed fauna included the barnacle S. balanoides and urchin S. droebachiensis, and there were rare occurrences of the mollusc Hiatella arctica and different sponge taxa (identified to genus, Table 2). Autotrophs like filamentous algae, Palmaria palmata, Ulva spp., and Porphyra spp. could be found in all habitats, but never in such abundance to generate differences between habitats. Overall, kelp forests were found in locations with greater sediment load, with and without the presence of bedrock or other hard substrate, while rhodoliths (live and dead) were only found in high flow channels within the Akia peninsula and the seaward Islands outside of Nuuk (Figure 1) and provided the primary substrate for their community. Bottom-dwelling or sessile communities are dominated by autotrophs, filter and mixed trophic feeders, suspension feeders and then grazers in both habitats.

The biodiversity of both types of interstitial communities was unique to each sediment matrix (the compact sediment in kelp habitats and spherical-nucleated or hollow rhodoliths in rhodolith beds). Rhodoliths provide a unique, porous matrix which housed the greatest species diversity in this study (Table 3). Worldwide, they are home to organisms in their juvenile stages $[62,63]$ and they are known to create a novel habitat in the other parts of the Arctic [34], which may also be true for Greenland. Many species such as brittle stars (Ophiura sarsi), common stars (Asteroidea), and crabs (Hyas coarctatus) were never observed in larger or adult forms on swaths or photo-quadrats, indicating that they may prefer an interstitial habitat, live in deeper habitats ( $>10 \mathrm{~m}$ depth), or have different habitat preferences throughout their life history. Burrowing bivalves were abundant in all grab surveys, and communities were unique to each habitat type; three species were found in kelp forests (Mytilus spp., Hiatella arctica, and Ennucula tenuis) and four in rhodolith beds (Macoma calcarea additionally). Cryptic species such as the worms, Amphipoda, and smaller molluscs were unique to the grabs surveys in all habitats and provide the most diverse range of trophic guilds quantified in these communities. There were fewer deposit feeders and detritivores than expected in these communities [46,47], which may be due to 
the low taxonomic resolution in species identification for annelid and arthropod groups. Similar to other Arctic studies [38,45], all surveys lacked ascidians, which can be seasonally abundant in coralline algae habitats elsewhere (Spring [64]), but generally contribute to the filter-feeding community in algal-dominated marine habitats $[46,65]$. It has been noted that ascidians are generally found in deeper waters of this region, ranked the third most abundant taxa in multiple habitats (soft and hard substrates [66]), but absences in shallow waters is not understood.

Overall, the three types of surveys were essential to creating a baseline for kelp forest and rhodolith communities and reveal significant differences between interstitial communities in kelp forest and rhodolith habitats. There was a high percentage of filter, suspension, and mixed feeders in faunal assemblages from all survey types, indicating that these communities are highly reliant on detrital and pelagic productivity. Molluscan and crustacean grazers are smaller organisms found only in the interstitial region of each habitat, suggesting that they consume smaller algae or particulate matter. A key Arctic grazer, S. droebachiensis (also classified as Predator and Deposit feeder in literature [50]), was common in kelp forests but highly abundant in rhodolith beds (Table 2) and may influence the presence of kelp in rhodolith beds, as suggested by Freiwald [12]. Urchins are known to devastate Norwegian kelp forests in the Arctic [67], and may restrict growth in Greenland [6], and kelp success in rhodolith beds could be confounded by other biotic and abiotic factors in the region (e.g., tidal flow). The greatest frequency of large mobile predators was found in swath surveys, but there were a significant number of smaller amphipod or molluscan predators in interstitial habitats. In the future, better taxonomic resolution and more intricate food-web studies may be able to tease out important interactions in these communities.

\subsection{Coralline Algae}

As the highest diversity of organisms and broadest array of functional groups exist interstitially in rhodolith beds, we suggest that these are critical repositories for marine biodiversity in this region. This study indicates that the diversity of a rhodolith bed does not hinge on the ratio of live:dead corallines in the habitat, indicating that rhodoliths have a structural role in their community over algal processes like primary production like that seen in UK maerl beds [62]. Few organisms actively eat coralline algae, most target epithelial organisms, only consuming corallines as a byproduct [35]. Most rhodoliths in this study were not-hollow (many rhodoliths had inorganic material as a nucleus); therefore, it is not the necessarily the rhodoliths, but the interstitial areas and stabilising effect of rhodoliths, that provides habitat and protection from potential predators, increasing the species richness and diversity in these communities [68]. These habitat may be attractive to larval stages of organisms as well; rhodolith habitats are settled on by larvae $\times 35$ more frequently than non-coralline habitats in Baja California [63], making them important for early life stages of marine species. This is something to consider in future investigation of Arctic coralline algae habitats.

These communities are important for carbon burial in this habitat, containing between 28.06 and $103.73 \mathrm{~g} \mathrm{CaCO}_{3} \cdot \mathrm{m}^{-3}$. This is an important consideration when determining community response to climate change, as higher $p \mathrm{CO}_{2}$ concentrations can cause some species to 'dissolve' or lose mass, releasing this carbon back into the environment [32,33]. Polar corallines are exposed to uniquely low levels of light throughout the year, and Greenlandic species have very efficient carbon concentrating mechanisms as well as control over surface chemistry that facilitates light-independent carbon fixation [69]. The $\mathrm{CaCO}_{3}$ deposits in this study may take years to accrue if calcification rates of -0.006-0.002 $\mu \mathrm{mol} \mathrm{CaCO} 3 \mathrm{~g}^{-1} \cdot \mathrm{h}^{-1}$ are maintained in Clathromorphum sp. throughout the summer months in this ecoregion (Nuuk, Greenland; [18]). Interestingly, in tropical reefs water flow is important for species to maintain positive calcification rates even under acidified conditions [70]. The channels where rhodolith beds exist have low sedimentation because of high water flow, which is beneficial to coralline algae [71], and may maintain water chemistry parameters where positive calcification is maintained. This, combined with regulatory control of surface $\mathrm{pH}$ and light independent carbon fixation, may facilitate perseverance of these communities in future ocean conditions. 
We assume that the sites surveyed in this study are representative of Clathromorphum spp.-dominated coralline algae communities and S. longicruris forests in the sub-Arctic; however, sites were at a maximum depth of $10 \mathrm{~m}$ due to logistical constraints for diving in the region. Deeper coralline algae and kelp beds can be found around Greenland [48], which may have different community composition, and certainly kelp communities far into the fjord system [19] may have different environmental conditions and species assemblages compared with those around Greenland's coast. Crustose coralline algae are known to be prolific components of sub-Arctic benthic communities [72-74], but often their ecological function in these systems is not always clear. Due to sloughing of external cells, coralline algae are known to deter certain algal species and biofilms from recruiting [75,76], but in other cases corallines have been seen to increase biodiversity by providing substrate for recruitment in later stages of succession. In Stefansson Sound, Alaska, cobbles and boulders without corallines present have three times the amount of red algal biomass [77] and this reduction of turf algae may be beneficial to canopy forming and the larger algal species [78] that provide food and habitat for many species. This dynamic is especially relevant in ocean acidification conditions, where increased $p \mathrm{CO}_{2}$ increases photosynthetic efficiency and benefits turf algal species while $\mathrm{pH}$ decreases, causing dissolution of calcified organisms and coralline algae [79]. Regime shifts to turf-dominated benthic systems are on the rise and decrease ecologically important macroalgae [80].

\subsection{Future Directions}

Many of the marine species in this study could only be described to class or family because of the limited knowledge on species in the sub-Arctic region of the north Atlantic. Future studies should focus on species richness and diversity in this region with better taxonomic resolution, perhaps modelled after hard-benthos studies in Svalbard [81,82], and food-web interactions within both kelp forests and coralline algae habitats. The predicted response of both communities to future ocean conditions [31] indicates that continued investigation into the ecology and species interactions will be important for assessing future communities (and fisheries) and mitigating loss in marine biodiversity. The work we present is the best description of these marine communities in this region to date.

Data from this manuscript is available through the University of Glasgow data repository, accessible via the University of Glasgow library system: http://researchdata.gla.ac.uk/. Voucher specimens for fleshy algae and marine invertebrates remain with K. Schoenrock at NUI Galway. Coralline algae vouchers are with P. Gabrielson at the University of North Carolina Chapel Hill herbarium.

Supplementary Materials: The following are available online at http:/ /www.mdpi.com/1424-2818/10/4/117/s1, Table S1: SIMPER analysis of marine communities using Euclidean distance for swath surveys ( $\mathrm{n}=1$ per site), using factor habitat (kelp forest vs. Rhodolith bed). The contribution of taxonomic units to dissimilarity of habitats within (across sites, $\mathrm{n}=4$ per habitat) and between kelp forests and rhodolith beds. Av value refers to abundance, sq distances refer to dissimilarity between habitats along and divided by the standard deviation, and \% contribution of each taxonomic unit to overall habitat dissimilarity within and across habitat types (average squared distance). Cut-off for low contributions was set at 90\%, Table S2: SIMPER analysis of marine communities using Euclidean distance for photo-quadrats surveys ( $\mathrm{n}=1$ per site), using factor habitat (kelp forest vs. Rhodolith bed). The contribution of taxonomic units (including substrate type) to dissimilarity of habitats within (across sites, $\mathrm{n}=4$ per habitat) and between kelp forests and rhodolith beds. Av value refers to abundance, sq distances refer to dissimilarity between habitats and divided by the standard deviation, and \% contribution of each taxonomic unit to overall habitat dissimilarity within and across habitat types (average squared distance). Cut-off for low contributions was set at 90\%, Table S3: SIMPER analysis of marine communities using Euclidean distance for grab surveys ( $n=5$ per site), using factor habitat (kelp forest vs. Rhodolith bed). The contribution of taxonomic units to dissimilarity of habitats within (across sites, $n=4$ per habitat) and between kelp forests and rhodolith beds. Av value refers to abundance, sq distances refer to dissimilarity between habitats along and divided by the standard deviation, and \% contribution of each taxonomic unit to overall habitat dissimilarity within and across habitat types (average squared distance). Cut-off for low contributions was set at $90 \%$.

Author Contributions: Conceptualization, K.M.S. and A.M.; Methodology, K.M.S. and A.M.; Formal Analysis, K.M.S.; Investigation, K.M.S., J.V., N.A.K.; Writing-Original Draft Preparation, K.M.S., A.M., and J.V.; Writing-Review \& Editing, D.M.P., J.E.S., B.R.R.; Project Administration, K.M.S., D.M.P., B.R.R.; Funding Acquisition, K.M.S., J.V., B.R.R., J.E.S. and N.A.K. 
Funding: Funding for this research was provided by a small grant from the Marine Alliance for Science and Technology for Scotland (MASTS) and the Scottish Alliance for Geoscience, Environment and Society (SAGES) "PECRE exchanges with Europe, North America, China, and India". The Leverhulme Trust Research Project Grant 2014-093 "Calving Glaciers: Long Term Validation and Evidence" funded field research activities and KMS at the University of Glasgow. JV was funded by the Natural Environment Research Council Centre for Doctoral Training in Oil \& Gas, received through Herriot-Watt University (James Watt Scholarship Scheme) and the British Geological Survey (British University Funding Initiative Scheme). JV would also like to acknowledge further support from Oil and Gas UK. AM was funded by the Environmental Protection Agency STAR Fellowship.

Acknowledgments: We would like to thank the GINR and the Nuuk Fire department for their assistance with laboratory and field logistics in Nuuk. We are also grateful to captain Mackenzie Haberman for her help in the field, and Drs Josephine Nymand, Martin Blicher, Thomas Juul-Pedersen for discussion of research topic and their help with site location and species identification during this research.

Conflicts of Interest: The authors declare no conflict of interest.

\section{References}

1. Blicher, M. Structure and Dynamics of Marine Macrozoobenthos in Greenland-and Link to Environmental Drivers; University of Copenhagen: København, Denmark, 2010.

2. Wiencke, C.; Amsler, C.D. Seaweeds and their communities in polar regions. In Seaweed Biology; Wiencke, C., Bischof, K., Eds.; Springer: Berlin, Germany, 2012; pp. 265-294.

3. Sakshaug, E. Primary and secondary production in the Arctic seas. In The Organic Carbon Cycle in the Arctic Ocean; Stein, R., MacDonald, R.W., Eds.; Springer: Berlin/Hiedelberg, Germany, 2004; pp. 57-81.

4. Bonsell, C.; Dunton, K.H. Long-term patterns of benthic irradiance and kelp production in the central Beaufort Sea reveal implications of warming for Arctic inner shelves. Prog. Oceanogr. 2018, 162, 160-172. [CrossRef]

5. Grebmeier, J.M. Shifting patterns of life in the Pacific Arctic and sub-Arctic seas. Annu. Rev. Mar. Sci. 2012, 4, 63-78. [CrossRef] [PubMed]

6. Krause-Jensen, D.; Marba, N.; Olesen, B.; Sejr, M.K.; Christensen, P.B.; Rodrigues, J.; Renaud, P.E.; Balsby, T.J.S.; Rysgaard, S. Seasonal sea ice cover as principal driver of spatial and temporal variation in depth extension and annual production of kelp in Greenland. Glob. Chang. Biol. 2012, 18, 2981-2994. [CrossRef] [PubMed]

7. Dunton, K.H. Growth of dark-exposed Laminaria sacchrina (L.) Lamour. and Laminaria solidungula J. Ag. (Laminariales: Phaeophyta) in the Alaskan Beaufort Sea. J. Exp. Mar. Biol. Ecol. 1985, 94, 181-189. [CrossRef]

8. IPCC. Summary for policymakers. In Climate Change 2013: The Physical Science Basis. Contribution of Working Group I to the Fifth Assessment Report of the Intergovernmental Panel on Climate Change; Stocker, T.F., Qin, D., Plattner, G.-K., Tignor, M., Allen, S.K., Boschung, J., Nauels, A., Xia, Y., Bex, V., Midgley, P.M., Eds.; Cambridge University Press: New York, NY, USA, 2013.

9. Dayton, P.K. Ecology of kelp communities. Annu. Rev. Ecol. Syst. 1985, 16, 215-245. [CrossRef]

10. Steneck, R.; Bourque, B.J.; Corbett, D.; Erlandson, J.M.; Estes, J.A.; Tegner, M.J. Kelp forest ecosystems: Biodiversity, stability, resilience and future. Environ. Conserv. 2002, 29, 426-459. [CrossRef]

11. Hop, H.; Wiencke, C.; Vogele, B.; Kovaltchouk, N.A. Species composition, zonation, and biomass of marine benthic macroalgae in Kongsfjorden, Svalbard. Bot. Mar. 2012, 55, 399-414. [CrossRef]

12. Freiwald, A. Coralline algal maerl frameworks-islands within the phaeophytic kelp belt. Facies 1993, 29, 133-148. [CrossRef]

13. Bartsch, I.; Wiencke, C.; Laepple, T. Global seaweed biogeography under a changing climate: The prospected effects of temperature. In Seaweed Biology; Wiencke, C., Bischof, K., Eds.; Springer: Berlin/Heidelberg, Germany, 2012.

14. Assis, J.; Lucas, A.V.; Barbara, I.; Serrao, E.A. Future climate change is predicted to shift long-term persistence zones in the cold-temperate kelp Laminaria hyperborea. Mar. Environ. Res. 2016, 113, 174-182. [CrossRef] [PubMed]

15. Assis, J.; Araujo, M.B.; Serrao, E.A. Projected climate changes threaten ancient refugia of kelp forests in the north Atlantic. Glob. Chang. Biol. 2018, 24, e55-e66. [CrossRef] [PubMed]

16. Brodie, J.; Williamson, C.J.; Smale, D.A.; Mieszkowska, N.; Santos, R.; Cunliffe, M.; Steinke, M.; Yesson, C.; Anderson, K.M.; Asnaghi, V.; et al. The future of the northeast Atlantic benthic flora in a high $\mathrm{CO}_{2}$ world. Ecol. Evol. 2014, 4, 2787-2798. [CrossRef] [PubMed] 
17. Fredriksen, S.; Bartsch, I.; Wiencke, C. New additions to the benthic marine flora of Kongsfjorden, western Svlabard, and comparison between 1996/1998 and 2012/2013. Bot. Mar. 2014, 57, 203-216. [CrossRef]

18. Schoenrock, K.M.; Bacquet, M.; Pearce, D.; Rea, B.; Schofield, J.E.; Lea, J.; Mair, D.; Kamenos, N. Influences of salinity on the physiology and distribution of the Arctic coalline algae, Lithothamnion glaciale Kjellman (Corallinales, Rhodophyta). J. Phycol. 2018, 54, 690-702. [CrossRef] [PubMed]

19. Schoenrock, K.M.; Stachnik, L.; Vad, J.; Kamenos, N.A.; Pearce, D.; Rea, B.; Schofield, J.E.; Lea, J.; Mair, D. Distribution of Benthic Communities in a Fjord-Marine System in Southwestern Greenland, with a Focus on Algal Dominated Habitats. In Proceedings of the International Youth Scientific and Practical Conference, "Arctic research: From extensive to integrated development", Arkhangelsk, Russia, 23-25 April 2018.

20. Gagnon, P.; Johnson, L.E.; Himmelman, J.H. Kelp patch dynamics in the face of intense herbivory: Stability of Agarum clathratum (Phaeophyta) stands and associated flora on urchin barrens. J. Phycol. 2005, 41, 498-505. [CrossRef]

21. Olesen, B.; Krause-Jensen, D.; Marba, N.; Christensen, P.B. Eelgrass Zostera marina in subarctic Greenland: Dense meadows with slow biomass turnover in cold waters. Mar. Ecol. Prog. Ser. 2015, 518, 107-121. [CrossRef]

22. Wulff, A.; Iken, K.; Quartino, M.L.; Al-Handal, A.; Weincke, C.; Clayton, M.N. Biodiversity, biogeography and zonation of marine benthic micro- and macroalgae in the Arctic and Antarctic. Bot. Mar. 2009, 52, 491-507. [CrossRef]

23. Bolton, J.J. Global seaweed diversity: Patterns and anomalies. Bot. Mar. 1994, 37, 241-246. [CrossRef]

24. Dunton, K.H.; Schell, D.M. Dependence of consumers on macroalgal (Laminaria solidundula) carbon in an Arctic kelp community: $\delta^{13} \mathrm{C}$ evidence. Mar. Biol. 1987, 93, 615-625. [CrossRef]

25. Hernandez-Kantun, J.J.; Hall-Spencer, J.M.; Grall, J.; Adey, W.; Rindi, F.; Maggs, C.A.; Barbara, I.; Pena, V. North Atlantic rhodolith beds. In Rhodolith/Maerl Beds: A Global Perspective; Riosmena-Rodrigeua, R., Ed.; Springer: Cham, Switzerland, 2017; pp. 265-279.

26. Filbee-Dexter, K.; Wernberg, T.; Fredriksen, S.; Norderhaug, K.M.; Pedersen, M.F. Arctic kelp forests: Diversity, resilience and future. Glob. Planet. Chang. 2019, 172, 1-14. [CrossRef]

27. Blicher, M.E.; Sejr, M.K.; Rysgaard, S. High carbon demand of dominant macrozoobenthic species indicates their central role in ecosystem carbon flow in a sub-Arctic fjord. Mar. Ecol. Prog. Ser. 2009, 383, 127-140. [CrossRef]

28. Krause-Jensen, D.; Marba, N.; Sanz-Martin, M.; Hendriks, I.E.; Thyrring, J.; Carstensen, J.; Sejr, M.K.; Duarte, C.M. Long photoperiods sustain high pH in Arctic kelp forests. Sci. Adv. 2016, 2, e1501938. [CrossRef] [PubMed]

29. Krause-Jensen, D.; Duarte, C.M.; Hendriks, I.E.; Meire, L.; Blicher, M.E.; Marba, N.; Sejr, M.K. Macroalgae contribute to nested mosaics of $\mathrm{pH}$ variability in a subarctic fjord. Biogeosciences 2015, 12, 4895-4911. [CrossRef]

30. Ramajo, L.; Perez-Leon, E.; Hendriks, I.E.; Marba, N.; Krause-Jensen, D.; Sejr, M.K.; Blicher, M.E.; Lagos, N.A.; Olsen, Y.S.; Duarte, C.M. Food supply confers calcifiers resistance to ocean acidification. Sci. Rep. 2016, 6, 19374. [CrossRef] [PubMed]

31. Harley, C.D.; Anderson, K.M.; Demes, K.W.; Kordas, J.P.; Coyle, T.A.; Graham, M.H. Effects of climate change on global seaweed communities. J. Phycol. 2012, 48, 1064-1078. [CrossRef] [PubMed]

32. McCoy, S.J.; Kamenos, N.A. Coralline algae (rhodophyta) in a changing world: Integrating ecological, physiological, and geochemical responses to global change. J. Phycol. 2015, 51, 6-24. [CrossRef] [PubMed]

33. Hofmann, L.C.; Bischof, K. Ocean acidification effects of calcifying macroalgae. Aquat. Biol. 2014, 22, $261-279$. [CrossRef]

34. Foster, M.S. Rhodoliths: Between rocks and soft places. J. Phycol. 2001, 37, 659-667. [CrossRef]

35. Steneck, R.S. The ecology of coralline algal crusts: Convergent patterns and adaptive strategies. Annu. Rev. Ecol. Syst. 1986, 17, 273-303. [CrossRef]

36. Chenelot, H.; Jewett, S.C.; Hoberg, M.K. Macrobenthos of the nearshore Aleutian Archipelago, with emphasis on invertebrates associated with Clathromorphum nereostratum (rhodophyta, corallinaceae). Mar. Biodivers. 2011, 41, 413-424. [CrossRef]

37. Freiwald, A.; Henrich, R. Reefal coralline algal build-ups within the Arctic circle: Morphology and sedimentary dynamics under extreme environmental seasonality. Sedimentology 1994, 41, 963-984. [CrossRef] 
38. Teichert, S. Hollow rhodoliths increase svalbard's shelf biodiversity. Sci. Rep. 2014, 4, 6972. [CrossRef] [PubMed]

39. Jiang, L.Q.; Feely, R.A.; Carter, B.R.; Greeley, D.J.; Gledhill, D.K.; Arzayus, K.M. Climatological distribution of aragonite saturation state in the global oceans. Glob. Biogeochem. Cycles 2015, 29, 1656-1673. [CrossRef]

40. Büdenbender, J.; Riebesell, U.; Form, A. Calcification of the arctic coralline red algae Lithothamnion glaciale in response to elevated $\mathrm{CO}_{2}$. Mar. Ecol. Prog. Ser. 2011, 441, 79-87. [CrossRef]

41. Krause-Jensen, D.; Duarte, C.M. Substatial role of macroalgae in marince carbon seqeustration. Nat. Geosci. 2016, 9, 737. [CrossRef]

42. Van der Heijden, L.H.; Kamenos, N.A. Reviews and syntheses: Calculating the global contribution of coralline algae to total carbon burial. Biogeosciences 2015, 12, 6429-6441. [CrossRef]

43. Rink, H. Grønland Geographisk og Statistisk Beskrevet; Andr. Fred. Høst: Copenhagen, Denmark, 1852; Volume I.

44. Matsunga, K.; Kawaguchi, T.; Suzuki, Y.; Nigi, G. The role of terrestrial humic substances on the shift of kelp community to crustose coralline algae community of the southern Hokkaido Island in the Japan Sea. J. Exp. Mar. Biol. Ecol. 1999, 241, 193-205. [CrossRef]

45. Gagnon, P.; Matheson, K.; Stapleton, M. Variation in rhodolith morphology and biogenic potential of newly discovered rhodolith beds in Newfoundland and Labrador (Canada). Bot. Mar. 2012, 55, 85-99. [CrossRef]

46. Grall, J.; Loc'h, F.L.; Guyonnet, B.; Riera, P. Community structure and food web based on stable isotopes $\left(\delta^{15} \mathrm{~N}\right.$ and $\left.\delta^{13} \mathrm{C}\right)$ analysis of a north eastern Atlantic maerl bed. J. Exp. Mar. Biol. Ecol. 2006, 338, 1-15. [CrossRef]

47. Gabara, S. Community Structure and Energy Flow within Rhodolith Habitats at Santa Catalina Island, CA; San Jose State University: Moss Landing, CA, USA, 2014.

48. Jørgensbye, H.I.; Halfar, J. Overview of coralline red algal crusts and rhodolith beds (Corallinales, Rhodophyta) and their possible ecological importance in Greenland. Polar Biol. 2017, 40, 517-531. [CrossRef]

49. Gabrielson, P.; University of North Carolina Chapel Hill, Chapel Hill, NC, USA. Personal communication, 2018.

50. Hayward, P.J.; Ryland, J.S. Marine Fauna of North-West Europe, 2nd ed.; Oxford University Press: Oxford, UK, 2017.

51. Kohler, K.E.; Gill, S.M. Coral point count with excel extensions (CPCe): A visual basic program for the determination of coral and substrate coverage using random point count methodology. Comput. Geosci. 2006, 32, 1259-1269. [CrossRef]

52. Oksanen, J.; Blanchet, F.G.; Friendly, M.; Kindt, R.; Legendre, P.; McGlinn, D.; Minchin, P.R.; O'Hara, R.B.; Simpson, G.L.; Solymos, P.; et al. Vegan: Community Ecology Package, 2.4-2. 2017. Available online: https:/ / cran.r-project.org,https:/ / github.com/vegandevs/vegan (accessed on 22 August 2018).

53. Clarke, K.R.; Gorley, R.N. Primer v6: User Manual/Tutorial; PRIMER-E: Plymouth, UK, 2006.

54. Foster, M.S. Algal succession in a Macrocystis pyrifera forest. Mar. Biol. 1975, 32, 313-329. [CrossRef]

55. Noble-James, T.; Jesus, A.; McBreen, F. Monitoring Guidance for Marine Benthic Habitats; JNCC Report No. 598; Joint Nature Conservation Committee: Peterborough, UK, 2017.

56. Fabry, V.J.; McClintock, J.B.; Mathis, J.T.; Grebmeier, J.M. Ocean acidification at high latitudes: The bellweather. Oceanography 2009, 22, 160-171. [CrossRef]

57. Reed, D.; Washburn, L.; Rassweiler, A.; Miller, R.; Bell, T.; Harrer, S. Extreme warming challenges sentinel status of kelp forests as indicators of climate change. Nat. Commun. 2016, 7, 12757. [CrossRef] [PubMed]

58. Wernberg, T.; Bennett, S.; Babcock, R.C.; Bettignies, T.D.; Cure, K.; Depczynski, M.; Dufois, F.; Fromont, J.; Fulton, C.J.; Hovey, R.K.; et al. Climate-driven regime shift of a temperate marine ecosystem. Science 2016, 353, 169-172. [CrossRef] [PubMed]

59. Karsten, U. Research note: Salinity tolerance of arctic kelps from Spitsbergen. Phycol. Res. 2007, 55, $257-262$. [CrossRef]

60. Polis, G.A.; Hurd, S.D. Linking marine and terrestrial food webs: Allochthonous input from the ocean supports high secondary productivity on small islands and coastal land communities. Am. Nat. 1996, 147, 396-423. [CrossRef]

61. Brand, M.; Fischer, P. Species composition and abundance of the shallow water fish community of Kongsfjorden, Svalbard. Polar Biol. 2016, 39, 2155-2167. [CrossRef]

62. Kamenos, N.A.; Moore, P.G.; Hall-Spencer, J.M. Nursery-area function of maerl grounds for juvenile Queen scallops Aequipecten opercularis and other invertebrates. Mar. Ecol. Prog. Ser. 2004, 274, 183-189. [CrossRef] 
63. Steller, D.L.; Caceres-Martinez, C. Coralline algal rhodoliths enhance larval settlement and early growth of the Pacific Calico Scallop Argopecten ventricosus. Mar. Ecol. Prog. Ser. 2009, 396, 49-60. [CrossRef]

64. Foster, M.S.; McConnico, L.C.; Lundsten, L.; Wadsworth, T.; Kimball, T.; Brooks, L.B.; Medina-Lopez, M.; Riosmena-Rodriguez, R.; Hernandez-Carmona, G.; Vasquez-Elizondo, R.M.; et al. Diversity and natural history of a Lithothamnion muelleri-Sargassum horridum community in the Gulf of California. Cienc. Mar. 2007, 33, 367-384. [CrossRef]

65. Stuart, V.; Klump, D.W. Evidence for food-resource partitioning by kelp-bed filter feeders. Mar. Ecol. Prog. Ser. 1984, 16, 27-37. [CrossRef]

66. Yesson, C.; Simon, P.; Chamshirova, I.; Gorham, T.; Turner, C.J.; Arboe, N.H.; Blicher, M.E.; Kemp, K.M. Community composition of epibenthic megafauna on the west Greenland shelf. Polar Biol. 2015, 38, 2085-2096. [CrossRef]

67. Leinaas, H.P.; Christie, H. Effecs of removing sea urchins (Strongylocentrotus droebachiensis): Stability of the barren state and succession of kelp forest recovery in the east Atlantic. Oecologia 1996, 105, 524-536. [CrossRef] [PubMed]

68. Steller, D.L.; Riosmena-Rodriguez, R.; Foster, M.S.; Roberts, C.A. Rhodolith bed diversity in the Gulf of California: The importance of rhodolith structure and consequences of disturbance. Aquat. Conserv. 2003, 13, S5-S20. [CrossRef]

69. Hofmann, L.C.; Schoenrock, K.M.; Beer, D.D. Arctic coralline algae elevate surface $\mathrm{pH}$ and carbonate in the dark. Front. Plant Sci. 2018, 9, 1416. [CrossRef] [PubMed]

70. Comeau, S.; Edmunds, P.J.; Lantz, C.A.; Carpenter, R.C. Water flow modulates the response of coral reef communities to ocean acidification. Sci. Rep. 2014, 4, 6681. [CrossRef] [PubMed]

71. Wilson, S.; Blake, C.; Berges, J.A.; Maggs, C.A. Environmental tolerances of free-living coralline algae (maerl): Importance for European marine conservation. Biol. Conserv. 2004, 120, 279-289. [CrossRef]

72. Roberts, R.D.; Kühl, M.; Glud, R.N.; Rysgaard, S. Primary production of crustose coralline red algae in a high Arctic fjord. J. Phycol. 2002, 38, 273-283. [CrossRef]

73. Adey, W.H.; Hayek, L.C. Elucidating marine biogeography with macrophytes: Quantitative analysis of the North Atlantic supports the thermogeographic model and demonstrates a distinct subarctic region in the northwest Atlantic. Northeast Nat. 2011, 18, 1-128. [CrossRef]

74. Teichert, S.; Woelkerling, W.; Rüggeberg, A.; Wisshak, M.; Piepenburg, D.; Meyerhöfer, M.; Form, A.; Büdenbender, J.; Freiwald, A. Rhodolith beds (Corallinales, Rhodophyta) and their physical and biological environment at $80^{\circ} 31^{\prime} \mathrm{N}$ in Nordkappbukta (Nordaustlandet, Svalbard Archipelago, Norway). Phycologia 2012, 51, 371-390. [CrossRef]

75. Johnson, C.R.; Mann, K.H. The crustose coralline alga, Phymatolithon foslie, inhibits the overgrowth of seaweeds without relying on herbivores. J. Exp. Mar. Biol. Ecol. 1986, 96, 127-146. [CrossRef]

76. Bulleri, F.; Bertocci, I.; Micheli, F. Interplay of encrusting coralline algae and sea urchins in maintaining alternative habitats. Mar. Ecol. Prog. Ser. 2002, 243, 101-109. [CrossRef]

77. Muth, A.; University of Texas at Austin, Port Aransas, TX, USA. Personal observation, 2018.

78. Burek, K.E.; Brien, J.M.; Scheibling, R.E. Wasted effort: Recruitment and persistence of kelp on algal turf. Mar. Ecol. Prog. Ser. 2018, 600,3-19. [CrossRef]

79. Kroeker, K.J.; Micheli, F.; Gambi, M.C. Ocean acidification causes ecosystem shifts via altered competetive interactions. Nat. Clim. Chang. 2013, 3, 156-159. [CrossRef]

80. Filbee-Dexter, K.; Wernberg, T. Rise of turfs: A new battlefront for globally declining kelp forests. Bioscience 2018, 68, 64-76. [CrossRef]

81. Voronkov, A.; Hop, H.; Gulliksen, B. Diversity of hard-bottom fauna relative to environmental gradients in Kongsfjorden, Svalbard. Polar Res. 2013, 32, 11208. [CrossRef]

82. Paar, M.; Voronkov, A.; Hop, H.; Brey, T.; Bartsch, I.; Schwanitz, M.; Wiencke, C. Temporal shift in biomass and production of macrozoobenthos in the macroalgal belt at Hansneset, Kongsfjorden, after 15 years. Polar Biol. 2016, 39, 2065-2076. [CrossRef]

(C) 2018 by the authors. Licensee MDPI, Basel, Switzerland. This article is an open access article distributed under the terms and conditions of the Creative Commons Attribution (CC BY) license (http:/ / creativecommons.org/licenses/by/4.0/). 